\title{
Insurance Payment Predicting Financial Risk Management Satisfaction of Malaysian Public Sector Employees
}

Husniyah, A. R., Zahariah, S., Amirah Shazana, M., Mohd. Amim, O., \& Mohd. Fazli, S.

To Link this Article: http://dx.doi.org/10.6007/IJARBSS/v11-i12/11791

DOI:10.6007/IJARBSS/v11-i12/11791

Received: 12 October 2021, Revised: 14 November 2021, Accepted: 26 November 2021

Published Online: 09 December 2021

In-Text Citation: (Husniyah et al., 2021)

To Cite this Article: Husniyah, A. R., Zahariah, S., Shazana, A. M., Mohd. Amim, O., \& Mohd. Fazli, S. (2021). Insurance Payment Predicting Financial Risk Management Satisfaction of Malaysian Public Sector Employees. International Journal of Academic Research in Business and Social Sciences, 11(12), 450-466.

Copyright: (c) 2021 The Author(s)

Published by Human Resource Management Academic Research Society (www.hrmars.com)

This article is published under the Creative Commons Attribution (CC BY 4.0) license. Anyone may reproduce, distribute, translate and create derivative works of this article (for both commercial and non0-commercial purposes), subject to full attribution to the original publication and authors. The full terms of this license may be seen at: http://creativecommons.org/licences/by/4.0/legalcode

Vol. 11, No. 12, 2021, Pg. 450 - 466

Full Terms \& Conditions of access and use can be found at http://hrmars.com/index.php/pages/detail/publication-ethics 


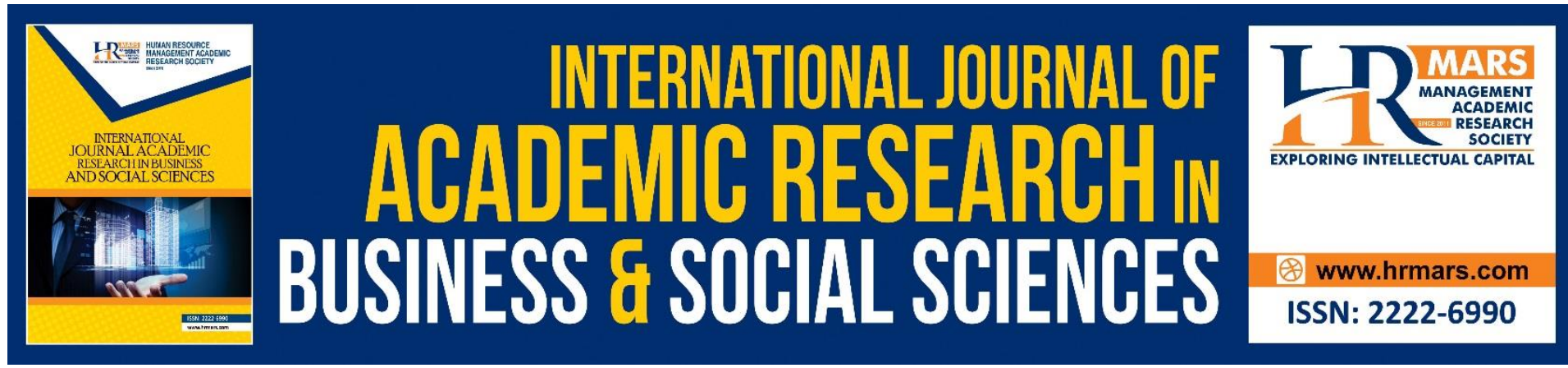

\title{
Insurance Payment Predicting Financial Risk Management Satisfaction of Malaysian Public Sector Employees
}

\author{
Husniyah, A. R. ${ }^{1}$, Zahariah, S. ${ }^{2}$, Amirah Shazana, M. ${ }^{1}$, Mohd. \\ Amim, $0 .{ }^{1}$, \& Mohd. Fazli, S. ${ }^{1}$ \\ ${ }^{1}$ Department of Resource Management \& Consumer Studies, Faculty of Human Ecology \\ Universiti Putra Malaysia, 43400 Serdang, Selangor, ${ }^{2}$ Universiti Teknologi MARA \\ Email: husniyah@upm.edu.my
}

\begin{abstract}
Risks are faced daily leading to unexpected bad events and incurring high costs. Notwithstanding, the differences in the ability to handle the situation may depend on their risk protection and financial preparedness. Thus, this study focused on the effect of insurance payment and financial preparedness among others, on the individuals' financial risk management satisfaction. A multistage random sampling resulted in 500 respondents selected among public sector employees. Logistic regression for 472 data from selfadministered questionnaires identified financial preparedness for old age, self-worth, financial risk knowledge, net-worth and insurance payment as influential predictors predicting the likelihood of the financial risk management satisfaction. Higher self-worth and financial risk knowledge, positive net-worth and higher insurance premium payment to cover risks faced would more likely predict individuals to be more satisfied with their financial risk management. Insurance payment was found to be the most influential predictor. Despite public workers having a low probability of the risk of losing jobs, nevertheless there is a need to have insurance protection for other financial risks. Hence, by purchasing insurance for various purposes, they would most probably be having a peace of mind in view of their risks. Keywords: Financial Risk Knowledge, Financial Risk Management Satisfaction, Insurance Payment, Net-Worth, Preparedness for Old Age
\end{abstract}

\section{Introduction}

In daily life, individual will face risks almost anywhere and anytime. Risks are associated with any activities and the unexpected bad events occurred would most probably lead to high costs. Despite that, the person's capability to handle the situation differs across individuals that depends on the extensiveness of their financial preparedness. Uncertainty in economic risks faced in daily life are such as loss of job, sickness, failure of loan repayment, bankruptcy, hardship and poverty or financial inadequacy at old age (Goldsmith, 2009). These economic risks may increase especially during pandemic due to the implementation of the Movement Control Order (MCO) for more than a year till now. 
Similar to the private sector employees, some public sector employees are also contributing to the Employee Provident Fund that depend on their retirement option. These employees thus are covered their work-related risks and also are being protected their long-term savings Social Security Organization scheme. However, not all risks are covered under these schemes. Local residents were facing other financial risks as shown by statistics of nonperforming loan with a total of 50,361 individuals were involved in a nonperforming loan (NPL) with an estimation of RM4.8 billion (Department of Statistic, 2010). NPL for consumer goods was recently RM2.1 million in May 2021 as compared to May 2020 that was RM1.6 million (Department of Statistic, 2021). While NPL for credit card was RM0.34 billion from RM0.31 billion and personal uses was RM2.1 billion from RM1.6 billion as compared to the previous year. The increase in NPLs among individuals were quite alarming. Hence, there is a need to manage risk well apart from managing spending, savings, loan and investment (Garman \& Forgue, 2003).

Managing daily risk comprises of four types of methods that are avoiding risk, reducing risk, assuming risk and transferring risk which involve along long-term effort. In transferring risk to a third party, individuals usually purchase an insurance company or fund institution. The Employee Provident Fund is a local fund institution that was set-up by the government for long-term savings. The fund is capable to manage savings risk faced by individuals where the risks of losing their savings are transferred to the institution. Restriction of withdrawal at an early age gives the safety feature of the long-term savings. The fund has a low liquidity as compared to the savings in savings or deposit accounts. Contributions based on salary are made by the employee and employer periodically over their life span during their service term. However, wise management of the retirement fund during retirement is crucial to sustain the money throughout the retirement period. As this study sampled the public sector employees, there is a regular income during the retirement period however with a lower amount. This is the situation for majority of them who had made option for the pension scheme. With a reduced income during retirement period, the pension income alone might not guarantee the adequacy of income for their retirement life.

Following the above, this study focused on the individuals' financial risk satisfaction towards risk management and the likelihood of prediction by various factors mainly by financial preparedness and other factors such as financial risk knowledge, self-worth and locus control of individuals.

\section{Literature Review}

The Risk Management Theory applied by Baek and DeVaney (2010) in their study was referred to in this study. The use of two methods in managing the risks that are the risk controlling and the risk financing were suggested. In controlling risk, this is to minimize the risks or problems through avoidance or reduction methods whilst in risk financing, it highlighted on the guarantee of fund in financing the losses occurred. Furthermore, other ways to finance risks through risk assumption method was by self-providing the fund while for the use of transfer risk method, individuals can purchase an insurance policy (Vaughan, 1997).

In managing financial matters, the individuals may display a risky or an unrisky behavior. The Risk Reduction Model that can be applied to financial behavior would be able to explain and predict the behavior and change efforts of individuals specifically in the management 
process (Ozmete \& Hira, 2011). The model on risk reduction focused on labeling the high financial risk behaviors as problematic individuals. Thus, making a commitment to change high financial risk behaviors and pursuing solutions in reducing the high financial risk activities. The factors affecting financial behavior include the choice that the individual have for a high-risk financial behavior and the knowledge of risky activities in the financial management process. Thus, by conducting the risk management process, the individuals have an option of selecting low-risk activities or otherwise. Their choices on the risky activities depend upon their personality and knowledge of risky activities. In avoiding risky activities or risky behavior, the individual would make believe that financial risks are undesirable to face and also by having the ability to identify the related cost and benefits. Hence, they tend to make financial decisions to solve problems occurred by choosing from the options that are available to them. Their choice would lead to the expected reduced financial risks and increased satisfaction towards their financial risk management.

Empirical past study was not found specifically for financial risk management satisfaction as what were available for financial satisfaction. Financial satisfaction is the extent to which individuals and families have financial adequacy and security (Xiao et al., 2006). Hira and Mugenda (1999a, 1999b) stated that multiple items were used to measure financial satisfaction including satisfaction with the amount of money saved, the amount of money owed, on the current financial situation, ability to meet long term goals, preparedness to meet emergencies and the skills in financial management. Financial risk satisfaction can be considered as one component in the financial satisfaction regarding the preparedness to meet financial emergencies.

Demographic, socioeconomic characteristics and behavioral factors such as education, financial knowledge, financial solvency, financial stress and financial behavior were found to have a direct effect on financial satisfaction among individuals (Davis \& Runyan, 2016; Husniyah et al., 2018; Joo \& Grable, 2004; Rutherford \& Fox, 2010; Shim et al., 2009; Xiao et al., 2014). Johnson and Krueger (2006); Plagnol (2010) revealed a positive relationship by income with financial satisfaction that resulted from increases in accumulated wealth. On the other hand, there may be due to a reduction in liabilities among individuals. In line with this, self-employed Swiss individuals exhibited a statistically significant higher income-ratio and improvement in financial satisfaction than employees (Zimmermann \& Zimmermann, 2021). The financial satisfaction among them improved with the increase of income-ratio.

Using Australian panel data, a study using objective measure of financial status found that self-reported household net-worth was an important factor influencing financial satisfaction (Headey \& Wooden, 2004). Hira (1989), in an earlier study noted that net-worth was found to influence financial satisfaction. Hence, in a similar manner, net-worth would be influencing financial risk management satisfaction as higher net-worth individual being affluent would be able to better manage their financial risk and thus be more satisfied. While the lack of emergency fund and committed to make repayment for student loan debt were the outstanding reasons for a lack of financial satisfaction, reflecting that savings and borrowing could both be associated with financial satisfaction (National Endowment for Financial Education, 2017). High savers would be able to use their savings to overcome the financial risks faced and they will most likely not to encounter difficulty in paying for the financial losses 
if the risks occur. Hence, savings would most probably be predicting the satisfaction on financial risk management.

The literature also suggests financial difficulties having a strong negative relationship with financial satisfaction in adults (Dowling et al., 2009; Joo \& Grable, 2004; Kim et al., 2003; Roberts \& Jones, 2001). Adults facing difficulties in their finances would not be able to prepare for any emergencies either in the short-term or the long-term, thus feeling unsatisfied with their management of financial risk. In the same vein, financial problems among adults would be predicting satisfaction on financial risk management. Financial behaviors that are compound traits were found to be related to financial situation (situational traits) and then to financial satisfaction that was classified as surface traits (Davis \& Runyan, 2016). Later, Xiao and Porto (2017) confirmed that subjective financial literacy and desirable financial behavior were strong mediators between financial education and financial satisfaction.

Apart from these factors, insurance practice was found earlier as an influential factor towards financial satisfaction (Sumarwan \& Hira, 1992). Their involvement in the insurance protection required them to pay a certain amount of premium regularly and by having this kind of protection against risk, they may feel financially satisfied. If risk occurred, they can be compensated for their losses which would ease their financial burden due to the perils. As mentioned by Kaplan et al (2017), purchasing health insurance assists consumers in elevating their financial satisfaction due to the financial wavier gained from the insurance policy. The financial waiver gained is dependent upon the insurance premium paid thus, the amount of the insurance premium would be influencing financial satisfaction and financial risk management satisfaction. More financial waiver gained, meaning that they are compensated highly of their financial risk and would be more satisfied. Due to this, insurance payment is justified to be affecting financial risk management satisfaction.

Psychological factors such as financial risk tolerance and self-worth were also found to have significant relationships with financial satisfaction (Grable \& Joo, 2001; Hira \& Mugenda, 1999b; Joo \& Grable, 2004). Grable and Joo (2004) stated that financial risk tolerance is the maximum amount of uncertainty that any individual is willing to accept in making decision on financial matters. A more risk tolerant individual in financial aspects and high self-worth individual would more likely be satisfied with their finances. Fauzi et al (2017) revealed a low level of financial risk tolerance reflecting a more risk-averse individual in their study on gold investment intention while Husniyah et al (2017) found a moderate level of financial risk tolerance in the study on health insurance purchase among Malaysian employees.

Studies on personal worth often used as self-esteem (Marsh et al., 2012), self-worth (Harter, 2012) and self-concept (Marsh et al., 2012) interchangeably as stated by Erdvik et al (2020). The self-worth concept measures the confidence level of individual's ability and their perception on the ability to do things as good as others (Hira \& Mugenda, 1999b). Self-worth was found to be at a high level among employees in the study on health insurance purchase (Husniyah et al., 2017). There were also no studies specifically assessing the influence of selfworth on financial risk management satisfaction. Past studies focused on various context among individuals. Global self-worth was found to be related with happiness (Bum \& Jeon, 2016) and had been revealed to be negatively associated to depressive symptoms (Bum \& Jeon, 2016) and risk of suicide (Singh \& Pathak, 2017). While self-worth was found to influence 
significantly financial behavior of university staffs (Grable \& Joo, 2001), however marginally significant in the influence on purchasing health insurance (Husniyah et al., 2017). In the context of satisfaction, Erdvik et al (2020) recently who did a study using structural equation modeling analyses among adolescents confirmed that global self-worth was related to basic need satisfaction in physical education. In line with this, the self-worth would be expected to influence financial risk management satisfaction as those who are high self-worth are confident with their ability and in managing financial risk.

Locus of control referred to the causes of the individuals' successes and failures either internal or external (Forte, 2005). Internal locus control individuals were stated by Rotter (1966) to exhibit two essential characteristics that are high achievement motivation and low outer-directedness. They are highly motivated without the influence from others and thus are high achievers. Internal locus control individuals display high motivation and more innerdirectness, hence they will be satisfied with things that they managed. Thus, it is proposed that internally locus control individual tend to be satisfied with their financial risk management. Davis and Runyan (2016) further suggested that trait characteristics such as need for material resources and emotional instability affected financial satisfaction. The need for control among individuals was found to be positively linked to their life satisfaction (Cummins \& Nistico, 2002), thus an internally locus control individual would be more satisfied with their lives. Parallel to this for financial satisfaction, domain on specific self-control bias had a positive and significant influence on financial satisfaction (Sahi, 2017). It is expected that an internally locus control individual would display higher financial risk management satisfaction.

Perceived financial preparedness for retirement is defined as the belief that current savings will be adequate for life in retirement (Hershey et al., 2010). Retirement studies are referring to the preparation for old age, thus financial preparedness to retirement is used interchangeably with financial preparedness for old age. The symbolic interaction theory explained the focus on the perceived aspects of preparedness. Descriptive results on the levels of financial preparedness for retirement are not much presented as inferential analysis results. One study on non-retired adults found that only about 20 per cent perceived themselves as financially prepared for retirement (Sege-Karpas \& Werner, 2014). The effects of retirement or old age planning showed various aspects impacted by the planning. Those individuals engaged in advance in retirement planning showed better physical (Topa et al., 2009; Yeung, 2013, 2017) and also gave psychological benefits (Noone et al., 2013; Sörensen et al., 2012). Following these, a sense of security or safety would be gained due to the early preparation. It would be expected that the actions taken in preparing for future financial security would minimize the financial risks during old age. Hence, it is proposed that perceived financial preparedness for old age would be predicting financial risk management satisfaction.

\section{Research Methodology}

A multistage random sampling was performed based on the lists of states, departments and name lists of public sector employees resulting in a total of 500 respondents being selected. However, usable questionnaires for data analysis were obtained as 472 . The minimum sample size required for a population having more than a million is 384 (Dillman et al., 2007). The Public Services Department had 1.6 million individuals working as civil servants (Department of Statistics Malaysia, 2018). A total of five states were randomly selected from 
12 states in Peninsula Malaysia in the first stage of sampling. Those selected were namely Pahang, Negeri Sembilan, Kelantan, Melaka and Johor. In the second stage of selection, from each of these state, one urban and one rural area were chosen followed by selecting a department from the public sector in each area. This gave a total of ten departments situated in those urban and rural areas. After granting permission from the selected departments, an officer in each department was contacted to assist in the random sampling of respondents. The liaison officer appointed did a random sampling based on the list of names of the employees in the department targeting 50 respondents from each.

The self-administered questionnaire form contained information on age, gender, marital status, family size, working experience, household income, financial risk knowledge, savings per income ratio (savings ratio), net-worth, financial problem, premium per income ratio (insurance payment), psychological factors namely self-worth and locus control, perceived financial preparedness for old age and financial risk management satisfaction. It was distributed to the respondents by liaison officer in the selected departments. Data on networth were obtained by comparing assets with liabilities and the frequency of financial problem was measured using a 5-point scale. In determining self-worth, the degree of agreement by the individual towards the statements reflecting self-worth was sought using a 5-point Likert scale while locus control was identified using a yes and no responses adapted from Rotter's Locus of Control Scale (1966). Perceived financial preparedness for old age was assessed using ordinal scale of adequacy. Measurement for financial risk management satisfaction as the dependent variable used a 5-point scale of satisfaction adapted from a past study comprised of the extent of satisfaction towards ways of facing risks for different type of risks (Power \& Hira, 2004). In the binomial logistic regression, the summed score of the dependent variable was being categorized into two groups of less satisfied and more satisfied towards handling financial risk based on the mean score.

Prior to collecting the data, a pre-test was performed among a public university staff to establish face validity. Reliability tests were to confirm on the internal consistencies of the statements in the measurements resulted in moderate to high reliabilities with alpha ranging from 0.639 to 0.874 and are considered as reliable measurements as the alpha values are more than 0.6 (Nunnally \& Bernstein, 1994). The distribution of the data for the variables were examined using descriptive analyses while binomial logistic regression was performed to identify the likelihood of the factors in predicting financial risk management satisfaction.

\section{Analysis of Results}

\section{Profile of Respondents}

The respondents' profile in this study is displayed in Table 1. Age was distributed across all categories of young and old, thus this study covers all the age groups of the working generation. Almost two-thirds of the respondents were male and married with moderate family size however with low working experience. Non-graduate were much more than the graduates and this justify the majority of the respondents earning monthly household income of less than RM3,500. This income is less than the mean monthly household income of the Malaysian population of RM7,901 (Department of Statistics Malaysia, 2019). It is in fact lower than the monthly household income of RM4,850 which falls in the bottom 40 per cent (B40) category of household income. 
Table 1: Profile of Respondents

\begin{tabular}{|c|c|c|}
\hline Socioeconomic Characteristics & Frequency $(N=472)$ & Percentage (\%) \\
\hline \multicolumn{3}{|l|}{ Age (years) } \\
\hline 19 to 28 & 100 & 21.5 \\
\hline 29 to 38 & 136 & 29.2 \\
\hline 39 to 48 & 116 & 24.9 \\
\hline More than 49 & 113 & 24.3 \\
\hline \multicolumn{3}{|l|}{ Gender } \\
\hline Male & 310 & 65.7 \\
\hline Female & 158 & 33.5 \\
\hline \multicolumn{3}{|l|}{ Marital Status } \\
\hline Single (unmarried/divorced/separated) & 93 & 20.0 \\
\hline Married & 373 & 80.0 \\
\hline \multicolumn{3}{|l|}{ Family size (persons) } \\
\hline 0 to 3 & 38 & 8.8 \\
\hline 4 to 6 & 228 & 53.0 \\
\hline 7 to 9 & 130 & 30.2 \\
\hline 10 to 13 & 34 & 7.9 \\
\hline \multicolumn{3}{|l|}{ Working experience (years) } \\
\hline 0 to 10 & 247 & 52.7 \\
\hline 11 to 20 & 95 & 20.3 \\
\hline More than 20 & 127 & 27.0 \\
\hline \multicolumn{3}{|l|}{ Education } \\
\hline Non-graduate & 389 & 82.8 \\
\hline Graduate & 81 & 17.2 \\
\hline \multicolumn{3}{|l|}{ Monthly Household Income } \\
\hline$<R M 3,500$ & 278 & 58.9 \\
\hline$\geq R M 3,500$ & 194 & 41.1 \\
\hline
\end{tabular}

Financial Matters

Information on their financial matters are displayed in Table 2. Majority of the respondents saved only a small portion of their income that is less than 20 percent of their income however, it is suggested to save at least 10 percent of the income each month (DeVaney, 1993). Majority of the respondents also pay the insurance premium with the same range of ratio. Those that had positive current net-worth were only one-third of them. Nevertheless, this is not a critical situation for them as half of them are still young and most 
probably are in the early stage of loan repayment. As a quarter of them are reaching retirement age, most of them might have paid a large portion of their loans leading to a one-third having positive net-worth.

Even with the small portion of regular savings and only one-third of them experiencing positive net-worth, it is found that more than half of the respondents perceived that their financial preparedness for their old age is adequate and more than adequate. This may be due to majority of them having guaranteed financial resources during retirement such as from pension and gratuity. A small portion (18.0\%) among the young employees opted for Employee Provident Fund (EPF) as a choice for their retirement fund. Older employees are not given the choice for EPF. This result on financial preparedness is different from a past study on non-retired adults (Sege-Karpas \& Werner, 2014). Results indicated that only about 20 per cent perceived themselves as financially prepared for retirement. 
Table 2: Financial Matters

\begin{tabular}{|c|c|c|}
\hline Variables & $\begin{array}{l}\text { Frequency } \\
(\mathrm{N}=472)\end{array}$ & $\begin{array}{c}\text { Percentage } \\
\text { (\%) }\end{array}$ \\
\hline \multicolumn{3}{|l|}{ Savings ratio (Saving per income ratio) } \\
\hline$<20 \%$ & 329 & 70.0 \\
\hline $20 \%-<40 \%$ & 119 & 25.3 \\
\hline$\geq 40 \%$ & 22 & 4.7 \\
\hline \multicolumn{3}{|c|}{ Insurance payment (Premium per income ratio) } \\
\hline$<20 \%$ & 305 & 73.7 \\
\hline $20 \%-<40 \%$ & 93 & 22.5 \\
\hline$\geq 40 \%$ & 16 & 3.9 \\
\hline \multicolumn{3}{|l|}{ Net-worth } \\
\hline Zero: Asset value = Debt value & 161 & 35.2 \\
\hline Positive: Asset value > Debt value & 148 & 32.3 \\
\hline \multicolumn{3}{|l|}{ Financial preparedness for old age } \\
\hline Inadequate & 203 & 43.0 \\
\hline Adequate & 256 & 54.2 \\
\hline More than adequate & 13 & 2.8 \\
\hline \multicolumn{3}{|l|}{ Financial Resources During Retirement } \\
\hline Pension/Gratuity & 404 & 85.6 \\
\hline$E P F$ & 85 & 18.0 \\
\hline Investment & 41 & 8.7 \\
\hline Savings & 175 & 37.1 \\
\hline Bank's Retirement Account & 26 & 5.5 \\
\hline Life Insurance/Takaful & 60 & 12.7 \\
\hline Children & 40 & 8.5 \\
\hline
\end{tabular}

Level for Variables

As shown in Table 3, self-worth and internal locus control of the respondents were at a high level. These respondents were confident with their ability of doing things. This is in line with a study by Husniyah et al. (2017) who found a high level of self-worth among employees in the public sector. The high level of internal locus control is parallel with their capability where those having high confident would display high motivation and more internally control behavior.

Table 3: Level for Variables

\begin{tabular}{lcccc}
\hline \multicolumn{1}{c}{ Variable } & Mean & $\begin{array}{c}\text { Standard } \\
\text { Deviation }\end{array}$ & Level & Range \\
\hline Self-worth & 3.80 & 0.180 & High & $1-5$ \\
Financial Problem & 2.09 & 0.283 & Low & $1-5$ \\
Satisfaction with Financial Risk Management & 3.22 & 0.198 & Moderate & $1-5$ \\
Internal Locus Control & 4.16 & 1.181 & High & $0-5$ \\
Financial Risk Knowledge & 7.84 & 1.580 & Moderate & $0-13$ \\
\hline
\end{tabular}


Meanwhile for financial risk knowledge and satisfaction with financial risk management, the respondents exhibited a moderate level of knowledge and satisfaction. The knowledge on risks faced regarding finances are known at a moderate level suggesting that they are not knowledgeable in certain aspects that would affect their finances. In view of this, they may be facing a substantial number of financial losses if the risks occurred. In line with this, their satisfaction with their management on financial risk would be at the same moderate level. Financial problem was experienced at a low level among the respondents reflecting a good situation of their finances.

\section{Predictors for Satisfaction with Financial Risk Management}

In determining the predictors for satisfaction with financial management among individuals, a binomial logistic regression was performed resulted in a fit model with a significant Omnibus test $\left(\chi^{2}=78.625 ; p=0.0001\right)$. Furthermore, the model is able to explain 28.2 percent of the variance in satisfaction with financial risk management with a moderate overall classification of 69.3 percent. Specifically, the model is able to correctly classify the respondents as less satisfied by 70.9 percent while correctly classifying the respondents into the more satisfied group by 69.3 percent. Socioeconomic characteristics such as age, gender, marital status, family size, working experience and household income were used as control variables.

Information regarding their financial matters such as financial risk knowledge, savings per income ratio, net-worth, financial problem, insurance payment and personality factors namely self-worth and locus control were included in the model other than perceived financial preparedness. Gender, marital status, savings per income ratio, net-worth and paying insurance premium were entered as categorical variables in the logistic regression analysis. Age, family size, working experience (years), household income, financial risk knowledge, financial problem and personality variables that are self-worth and locus control were entered as continuous variables. The satisfaction with financial risk management was entered as a categorical variable with two outcomes either being less satisfied or more satisfied. The results of the binomial logistic regression are tabulated in Table 4.

Table 4: Binomial Logistic Regression of Financial Risk Management Satisfaction

\begin{tabular}{lccccc}
\hline & B & S. E. & Wald & Sig. & Exp.(B) \\
\hline Constant & -4.969 & 1.323 & 14.108 & 0.000 & 0.007 \\
Age & -0.020 & 0.023 & 0.811 & 0.368 & 0.980 \\
Male & 0.311 & 0.283 & 1.204 & 0.273 & 0.733 \\
Married & 0.206 & 0.368 & 0.313 & 0.576 & 1.229 \\
Family size & -0.033 & 0.054 & 0.376 & 0.539 & 0.968 \\
Working experience & 0.014 & 0.021 & 0.490 & 0.484 & 1.015 \\
Household income & 0.000 & 0.000 & 0.573 & 0.449 & 1.000 \\
Internal locus control & -0.146 & 0.112 & 1.703 & 0.192 & 0.864 \\
Self-worth & 0.273 & 0.057 & 22.609 & $0.000^{* *}$ & 1.313 \\
Financial risk knowledge & 0.149 & 0.075 & 3.910 & $0.048^{*}$ & 1.161 \\
Financial problem & -0.039 & 0.022 & 3.183 & 0.074 & 0.962 \\
Positive net-worth & 0.588 & 0.274 & 4.595 & $0.032^{*}$ & 1.801 \\
Savings per income ratio $\geq 20 \%$ & 0.126 & 0.279 & 0.204 & 0.651 & 1.134 \\
Premium per income ratio $\geq 20 \%$ & 0.684 & 0.301 & 5.131 & $0.024^{*}$ & 1.983 \\
Financial preparedness for old age & 0.591 & 0.276 & 0.4566 & $0.033^{*}$ & 1.805 \\
\hline
\end{tabular}

* Significant at $p \leq 0.05, * *$ Significant at $p \leq 0.01$ 
The Wald value in the output provided the statistical significance for each estimated coefficient that was labeled as B. A positive value of B gives a prediction of feeling more satisfied with financial risk management by the independent variables and in contrast, a negative B value will predict the likelihood of feeling less satisfied with financial risk management. The respondent's backgrounds were not found to be significantly predicting financial risk management satisfaction. Age of the respondent, gender, marital status, family size, work experience and household income cannot ascertain the occurrence of feeling more satisfied or less satisfied with financial risk management. However, past research found income affecting financial satisfaction (Johnson \& Krueger, 2006; Plagnol, 2010; Zimmermann \& Zimmermann, 2021) and no empirical studies were found on financial risk management satisfaction.

Respondents' locus control, whether they are facing any financial problem or making regular savings were also found to be not significant in determining the likelihood of them feeling satisfied with financial risk management. Thus, after controlling for the effects of other variables in the model, the logistic regression analysis was able to identify self-worth, financial risk knowledge, net-worth, paying insurance premium and financial preparedness for old age as influential predictors predicting the probability to be more satisfied or less satisfied with their financial risk management. Having higher self-worth and financial risk knowledge, positive net-worth, purchasing insurance to cover various risks faced and being financially prepared for old age would more likely predict individuals to be more satisfied with their financial risk management. Positive influences by self-worth, financial knowledge, net-worth and insurance payment on financial satisfaction were found in past studies (Erdvik et al., 2020; Headey \& Wooden, 2004; Hira, 1989; Kaplan et al., 2017; National Endowment for Financial Education, 2017; Sumarwan \& Hira, 1992; Xiao et al., 2014; Xiao \& Porto, 2017).

Higher self-worth person is a person that feels more confident with their ability to do things, thus, with this kind of feeling, they would most probably be more satisfied with anything that they do such as towards their financial risk management. This result is in line with the result of a study by Erdvik et al (2020) stating that global self-worth was related to basic need satisfaction in physical education though this is focusing on a different aspect of satisfaction. Individual with a higher self-worth is 31.3 per cent more likely for the person to be satisfied with financial risk management. Based on the beta value, this is the fourth influential predictor of the satisfaction on financial risk management.

Past studies only studied on the relationships between financial literacy and financial education with financial satisfaction but not in the context of financial risk management (National Endowment for Financial Education, 2017; Xiao et al., 2014; Xiao \& Porto, 2017) where the relationships were positive. In this study, financial risk knowledge that is the fifth influential predictor was significantly predicting financial risk management satisfaction at 95 per cent confidence level. Thus, those knowledgeable about financial risk would be 16.1 per cent more likely to be satisfied with how they manage their financial risk. By understanding and know the financial risks that they would face, then suitable actions could be identified in managing those financial risks.

Positive net-worth that is the third influential predictor was 80.1 percent more likely to predict a person to be more satisfied with their financial risk management as compared with 
being less satisfied. Past studies on net-worth were only on satisfaction in general (Headey \& Wooden, 2004; Hira, 1989). Nevertheless, a similar trend would be expected for satisfaction on financial risk management as high net-worth individuals are those having assets surpassing their liability values. With a high net-worth, they are able to provide funds to face financial risk, and thus would be satisfied with their financial risk management.

High premium payment for the insurance measured by premium per income ratio exceeding 20 percent of the income was found to be the most influential predictor. Those paying high premium for insurance coverage were those that would be almost two times more satisfied with their financial risk management as compared to be less satisfied. With higher premium paid, individuals were more protected against financial risk as larger amount of compensation are claimable upon risk faced. This suggests that without purchasing insurance, they would more likely feel less satisfied with their financial risk management. This result on the significant influence by insurance payment is in line with the results found by (Kaplan et al., 2017; Sumarwan and Hira., 1992).

The second influential predictor was financial preparedness for old age with an 80.5 per cent likelihood to be more satisfied with their financial risk management as compared to being less satisfied. As mentioned by Noone et al (2013); Sörensen et al (2012), individuals involved in retirement planning in their early lives affect them psychologically as they feel safe and secure when thinking about retirement or their life at old age. The financial risks that they foresee during their retirement or old age are minimized. Thus, this significant result for the perception on their financial preparedness for old age which gives this factor as the second important predictor on financial risk management satisfaction can be justified by earlier findings on the old age preparedness.

\section{Conclusion and Implication}

Several factors were found to be significantly predicting the likelihood of being satisfied with financial risk preparation. Financial preparedness for old age, self-worth, financial risk knowledge, net-worth and paying higher insurance premium were found to be the influential factors predicting financial risk management satisfaction. Individuals tend to be satisfied with their financial risk management with higher self-worth and financial risk knowledge, positive net-worth and largely covered by insurance policy. The extent of premium amount was among those factors found to be the most influential predictor with those paying high premium for insurance coverage are more likely to be more satisfied with their financial risk management as compared to be less satisfied.

The results of this study concluded that those workers, who are not highly protected against financial risks due to small premium payment, will feel less satisfied with their financial risk management. This reflects that the protection against financial risks which are available to them such as having long-term savings in the fund for employees namely the Employee Provident Fund, being protected from risks faced during work under the Social Security Organization or being covered by group insurance purchased by employers are insufficient as perceived by them. It implies the need of having insurance to protect them from several other financial risks not covered by the available schemes. Even though as public workers, they will most probably be facing low risk of losing jobs, however there is a need to have insurance protection for other financial risks. Those involved in risky jobs such as 
veterinarians or handling animals would be facing the risks of being injured while dealing with the animals during their work. As for now, there is no such insurance purchased for these employees. Due to this, they will seek the help from their association to have a group insurance regarding this kind of risk.

Though the study found significant results in the prediction of financial risk management satisfaction, the study is not directly comparable to any past studies as there are no empirical studies examining this aspect of satisfaction in managing financial risk. Studies on satisfaction in managing finances were the basis for this study to justify the significant factors. Thus, this study sets a path to determine influential predictors for financial risk management satisfaction in enabling stakeholders to develop further actions for the benefit of the employees.

As various risks are faced at any time of life with some risks are job-related risks, the available protection against risks is perceived as inadequate, thus the relevant government agencies or employers should review the available schemes to fulfill the needs of workers. Hence, by purchasing insurance for various purposes, they would most probably be having a peace of mind. In conjunction with these, insurance companies should identify the various risks faced by individuals especially those that are job-related and developing specific insurance policies tailored to the needs of the employees. Employers may discuss with insurance companies to tailor made the insurance or takaful policies for the benefit of their employees. This will contribute to the growth of the insurance industry in the long run.

\section{References}

Baek, E., \& DeVaney, S. A. (2010). How do families manage their economic hardship? Family Relations, 59, 358-368.

Bum, C., \& Jeon, I. (2016). Structural relationships between students' social support and selfesteem, depression, and happiness. Social Behavior \& Personality: An International Journal, 44(11), 1761-1774.

Cummins, R. A., \& Nistico, H. (2002). Maintaining life satisfaction: The role of positive cognitive bias. Journal of Happiness Studies, 3, 37-69.

Davis, K., \& Runyan, R. C. (2016). Personality traits and financial satisfaction: Investigation of a hierarchical approach. Journal of Financial Counseling and Planning, 27(1), 47-60.

Department of Statistics Malaysia. (2010). Non-performing loan. Department of Statistics Malaysia.

Department of Statistics Malaysia. (2018). Labour force survey. Department of Statistics Malaysia.

Department of Statistics Malaysia. (2019). Household Income and Basic Amenities (HIS/BA) survey of 2019. Department of Statistics Malaysia.

Department of Statistics Malaysia. (2021). Non-performing loan. Department of Statistics Malaysia.

DeVaney, S. A. (1993). Change in household financial ratios between 1983 and 1986: Were American households improving their financial status. Financial Counseling and Planning, 4(3), I-46.

Dillman, D. A., Stern, M. J., \& Smyth, J. D. (2007). European survey research association visual design, order effects, and respondent characteristics in a self-administered survey. Survey Research Methods, 1(3), 121-138. 
Dowling, N. A., Corney, T., \& Hoiles, L. (2009). Financial management practices and money attitudes as determinants of financial problems and dissatisfaction in young male Australian workers. Journal of Financial Counseling and Planning, 20(2), 5-13.

Erdvik, I. B., Haugen, T., Ivarsson, A., \& Säfvenbom, R. (2020). Global self-worth among adolescents: The role of basic psychological need satisfaction in physical education. Scandinavian Journal of Educational Research, 64(5), 768-781.

Forte, A. (2005). Locus of control and the moral reasoning of managers. Journal of Business Ethics, 58(1), 65-77.

Garman, E. T., \& Forgue, R. (2003). Personal finance. (Seventh Ed.). Houghton Mifflin.

Goldsmith, E. (2009). Resource management for individuals and family. Wadsworth.

Grable, J. E., \& Joo, S. H. (2001). A further examination of financial help-seeking behaviour. Journal of Financial Counselling and Planning, 12(1), 55.

Grable, J. E., \& Joo, S. H. (2004). Environmental and biopsychosocial factors associated with financial risk tolerance. Journal of Financial Counseling and Planning, 15, 73-82.

Harter, S. (2012). Self-perception profile for adolescents: Manual and questionnaires. University of Denver.

Headey, B., \& Wooden, M. (2004). The effects of wealth and income on subjective wellbeing and ill-being. Economic Record, 80, 24-33.

Hershey, D. A., Henkens, K., \& Van Dalen, H. P. (2010). Aging and financial planning for retirement: Interdisciplinary influences viewed through a cross-cultural lens. The International Journal of Aging and Human Development, 70(1), 1-38.

Hira, T. (1993). The effects of perceived locus of control and perceived income adequacy on satisfaction with financial status of rural households. Journal of Family and Economic Issues, 343-364.

Hira, T. K., \& Mugenda, O. (1999a). Do men and women differ in their financial beliefs and behaviors? In Kitt, K. (Eds.), Proceedings of Eastern Family Economics Resource Management Association (pp. 1-8).

Hira, T. K., \& Mugenda, O. (1999b). The relationship between self-worth and financial beliefs, behavior, and satisfaction. Journal of Family and Consumer Sciences, 91(4), 76-82.

Johnson, W., \& Krueger, R. F. (2006). How money buys happiness: Genetic and environmental processes linking finances and life satisfaction. Journal of Personality and Social Psychology, 90, 680-691.

Joo, S., \& Grable, J. E. (2004). An exploratory framework of the determinants of financial satisfaction. Journal of Family and Economic Issues, 25(1), 25-50.

Kaplan, G., Shahar, Y., \& Tal, O. (2017). Supplementary health insurance from the consumer point of view: Are Israelis consumers doing an informed rational choice when purchasing supplementary health insurance? Health Policy, 121, 708-714.

Kim, J., Garman, E. T., \& Sorhaindo, B. (2003). Relationships among credit counseling clients' financial well- being, financial behaviors, financial stressor events, and health. Financial Counseling and Planning, 14, 75-87.

Marsh, H. W., Xu, M., \& Martin, A. J. (2012). Self-concept: A synergy of theory, method, and application. In Harris, K. R., Graham, S., \& Urdan, T. (Eds.). APA educational psychology handbook. American Psychological Association.

National Endowment for Financial Education. (2017). 1 in 3 say financial life is worse than they expect it to be. [Press room news]. Retrieved from http://www. nefe.org/pressroom/news/tips-for-getting-financiallyfit-in-2017.aspx 
Noone, J., O'Loughlin, K., \& Kendig, H. (2013). Australian baby boomers retiring 'early': Understanding the benefits of retirement preparation for involuntary and voluntary retirees. Journal of Aging Studies, 27, 207-217.

Nunnally, J. C., \& Bernstein, I. H. (1994). The assessment of reliability. Psychometric Theory, 3(1), 248-292.

Ozmete, E., \& Hira, T. K. (2011). Conceptual analysis of behavioral theories/models: Application to financial behavior, European Journal of Social Sciences, 18(3), 386-404.

Plagnol, A. C. (2010). Financial satisfaction over the life course: The influence of assets and liabilities. Journal of Economic Psychology, 32(1), 45-64. doi:10.1016/j.joep.2010.10.006

Power, L. M., \& Hira, T. K. (2004). University provided retirement planning support and retiree financial satisfaction during retirement: Differences by gender, job classification, and planning behaviour. Risk Management and Insurance Review, 7(2), 121-149.

Roberts, J. A., \& Jones, E. (2001). Money attitudes, credit card use, and compulsive buying among American college students. Journal of Consumer Affairs, 35, 213-240.

Rotter, J. B. (1966). Generalized expectancies for internal versus external control reinforcement. Psychological Monographs: General and Applied, 80(1), 1.

Rutherford, L. G., \& Fox, W. S. (2010). Financial wellness of young adults age 18-30. Family and Consumer Sciences Research Journal, 38(4), 468-484.

Sahi, S. (2017). Psychological biases of individual investors and financial satisfaction. Journal of Consumer Behavior. 1-25.

Segel-Karpas, D., \& Werner, P. (2014). Perceived financial retirement preparedness and its correlates: A national study in Israel. The International Journal of Aging and Human Development, 79(4), 279-301.

Shim, S., Xiao, J. J., Barber, B. L., \& Lyons, A. C. (2009). Pathways to life success: A conceptual model of financial well-being for young adults. Journal of Applied Developmental Psychology, 30, 708-723.

Singh, R. N., \& Pathak, N. (2017). Effects of self-esteem on suicidal ideation among adolescents. International Journal of Indian Psychology, 4(4), 60-68.

Sörensen, S., Mak, W., Chapman, B., Duberstein, P. R., \& Lyness, J. M. (2012). The relationship of preparation for future care to depression and anxiety in older primary care patients at 2-year follow-up. American Journal of Geriatric Psychiatry, 20, 887-894.

Sumarwan, U., \& Hira, T. K. (1992). Credit, saving and insurance practices influencing satisfaction with preparation for financial emergencies among rural households. Home Economics Research Journal, 21(2), 206-227.

Topa, G., Moriano, J. A., Depolo, M., Alcover, C.-M., \& Morales, J. F. (2009). Antecedents and consequences of retirement planning and decision-making: A meta-analysis and model. Journal of Vocational Behavior, 75, 38-55.

Vaughan, E. J. (1997). Risk management. John Wiley \& Sons.

Xiao, J. J., Chen, C., \& Chen, F. (2014). Consumer financial capability and financial satisfaction. Social Indicators Research, 118(1), 415-432.

Xiao, J. J., \& Porto, N. (2017). Financial education and financial satisfaction: Financial literacy, behavior, and capability as mediators. International Journal of Bank Marketing, 35(5), 805-817.

Xiao, J. J., Sorhaindo, B., \& Garman, E. T. (2006). Financial behaviours of consumers in credit counseling. International Journal of Consumer Studies, 30, 108-112. 
Yeung, D. Y. (2013). Is pre-retirement planning always good? An exploratory study of retirement adjustment among Hong Kong Chinese retirees. Aging \& Mental Health, 17, 386-393.

Yeung, D. Y., \& Zhou, X. (2017). Planning for retirement: Longitudinal effect on retirement resources and post-retirement well-being. Frontiers in Psychology, 8, 1300.

Zimmermann, Y. S., \& Zimmermann, H. (2021). How does income and financial satisfaction change with retirement? Insights from Swiss panel data. Wealth Management eJournal, 1-31. 